\title{
Pengaruh Model Pembelajaran Course Review Horay Terhadap Hasil Belajar IPA Siswa
}

\author{
Ni Wayan Arsani ${ }^{*}$, D.B. K. N. S. Putra ${ }^{2}$, I K. Ardana ${ }^{3}$ \\ 1,2,3 Jurusan Pendidikan Guru Sekolah Dasar, FIP Universitas Pendidikan Ganesha, Singaraja
}

\section{ARTICLEIN $\mathrm{FO}$ Article history: Received 17 May 2018 \\ Received in revised form \\ 19 June 2018 Accepted 15 July 2018 \\ Available online 28 \\ August 2018}

Kata Kunci:

Model Pembelajaran

Course Review

Horay, Hasil Belajar IPA.

Keywords: Learning Model Course Review Horay, Science Learning Outcomes.

\begin{abstract}
A B S TR A K
Penelitian ini bertujuan untuk mengetahui perbedaan yang signifikan hasil belajar IPA siswa yang dibelajarkan melalui model pembelajaran Course Review Horay dan siswa yang dibelajarkan melalui pembelajaran konvensional. Jenis penelitian ini merupakan jenis penelitian quasi eksperimen dan menggunakan desain penelitian Non-equivalent Control Group Design. Populasi dari penelitian ini adalah seluruh siswa kelas V SD Gugus III Kuta Utara dengan jumlah populasi 527 orang siswa. Sampel dalam penelitian ini berjumlah 65 orang siswa yaitu 35 orang siswa kelas VA dari SD No.1 Kerobokan Kaja yang menjadi kelompok eksperimen dan 30 orang siswa kelas VB dari SD No.2 Kerobokan Kaja yang menjadi kelompok kontrol. Pemilihan sampel dalam penelitian ini menggunakan teknik random sampling. Data hasil belajar IPA siswa dikumpulkan menggunakan metode tes yang kemudian dianalisis menggunakan uji-t. Hasil penelitian menunjukkan nilai rata-rata kelompok eksperimen lebih tinggi daripada nilai rata-rata kelompok kontrol $(83,54>75,63)$. Berdasarkan hasil analisis uji-t dengan derajat kebebasan ( $\mathrm{dk}=35+30-2=63$ ) dan pada taraf signifikan $5 \%$ diperoleh thitung > ttabel $(3,795>2,000)$ maka $\mathrm{HO}$ ditolak dan $\mathrm{Ha}$ diterima. Dengan demikian dapat disimpulkan, bahwa terdapat perbedaan yang signifikan hasil belajar IPA siswa yang dibelajarkan melalui model pembelajaran Course Review Horay dan siswa yang dibelajarkan melalui pembelajaran konvensional. Ini berarti model pembelajaran Course Review
\end{abstract} Horay berpengaruh terhadap hasil balajar IPA siswa kelas V SD Gugus III Kuta Utara Tahun Ajaran 2017/2018.

\section{A B S T R A C T}

This study aims to determine the significant differences in the results of science learning of students who are learned through Course Review Horay learning model and students who learned through conventional. This experiment is a quasi experiment and the experiment's design that be used is nonequivalent control group design. The population of this study is all students of grade V SD Gugus III Kuta Utara with a population of 527 students. The sample in this study amounted to 65 students ie 35 VA class students from SD No.1 Kerobokan Kaja as the experimental group and 30 students of VB grade from SD No.2 Kerobokan Kaja as the control group. Sample selection in this study using random sampling technique. Students' learning outcomes were collected using test methods which were then analyzed using the t-test. The results showed that the experiment group average is higher than the control group average $(83,54>75,63)$. Based on the result of t-test analysis with degrees of freedom ( $\mathrm{dk}=35+30-2=63)$ and at $5 \%$ significant level obtained tcount $>$ ttable $(3.795>2,000)$ then $\mathrm{HO}$ rejected and $\mathrm{Ha}$ accepted. Thus it can be concluded that there is a significant difference of science learning outcomes of students who are learned through Course Review Horay model and students learning through conventional. This means that the Course Review Horay learning model has an effect on the result of the students' learning grade V SD Gugus III Kuta Utara in $2017 / 2018$.

\footnotetext{
Corresponding author.

E-mail addresses: arsani96.niwayan@gmail.com (Ni Wayan Arsani)
} 


\section{Pendahuluan}

Pendidikan adalah segala pengalaman belajar yang berlangsung dalam segala lingkungan dan sepanjang hidup. Menurut Dharsana (2017:22) Pendidikan merupakan upaya bimbingan yang berpusat pada diri peserta didik yang dalam perkembangannya selalu berhubungan dan dipengaruhi lingkungannya. "pendidikan adalah pengajaran yang diselenggarakan di sekolah sebagai lembaga tempat mendidik (mengajar)" (Soyomukti 2016:30). Jadi dapat disimpulkan bahwa pendidikan sangat penting karena tanpa pendidikan manusia akan sulit berkembang dan bahkan akan terbelakang, sehingga pendidikan harus benarbenar diarahkan untuk menghasilkan manusia yang berkualitas dan mampu bersaing serta memiliki budi pekerti yang luhur dan moral yang baik, bahkan sangat menentukan berhasil tidaknya pembangunan suatu bangsa. Pendidikan di sekolah dasar harus diperhatikan karakteristik siswa yaitu suka bermain, memiliki rasa ingin tahu yang besar, mudah terpengaruh oleh lingkungan, dan gemar membentuk kelompok sebaya. Pendidikan sangat penting karena tanpa pendidikan manusia akan sulit berkembang dan bahkan akan terbelakang, sehingga pendidikan harus benar-benar diarahkan untuk menghasilkan manusia yang berkualitas dan mampu bersaing serta memiliki budi pekerti yang luhur dan moral yang baik, bahkan sangat menentukan berhasil tidaknya pembangunan suatu bangsa.

Berdasarkan hasil wawancara dan observasi menunjukkan bahwa pembelajaran yang berlangsung masih didominasi oleh pembelajaran KTSP, dimana partisipasi siswa dalam proses pembelajaran belum optimal karena pembelajarannya satu arah. Hal tersebut tentunya menyebabkan pembelajaran kurang menarik dan kurang menyenangkan. Maka perlu adanya perubahan dalam proses pembelajaran agar lebih kreatif, inovatif, dan menarik perhatian siswa salah satunya pada mata pelajaran IPA. Belajar merupakan suatu proses yang sangat penting bagi manusia, karena manusia membutuhkan waktu lama untuk belajar untuk menjadi manusia yang dewasa dam memiliki pandangan yang luas. Menurut Gagne (1988:17) "belajar merupakan proses yang memungkinkan makhluk-makhluk ini merubah perilakunya cukup cepat dalam cara yang kurang lebih sama, sehingga perubahan yang sama tidak harus terjadi lagi dan lagi pada setiap situasi baru". Menurut Susanto (2013:1) "Belajar dan mengajar merupakan dua konsep yang tidak dapat dipisahkan satu sama lain. Dua konsep ini menjadi terpadu dalam satu kegiatan dimana terjadi interaksi antara guru dengan siswa, serta siswa dengan siswa pada saat pembelajaran berlangsung". Belajar merupakan suatu perubahan dalam tingkah laku, dimana perubahan itu dapat mengarah kepada tingkah laku yang lebih baik, tetapi juga ada kemungkinan mengarah kepada tingkah laku yang lebih buruk (Dharsana, 2017:171). Melihat pentingnya pendidikan IPA di Indonesia, khususnya pada jenjang sekolah dasar, Kaminar (2016) menyatakan, Pendidikan IPA diharapkan dapat menjadi wahana bagi siswa untuk mempelajari diri sendiri dan alam sekitar serta prospek pengembangan lebih lanjut dalam menerapkannya di dalam kehidupan sehari hari. Proses pembelajarannya menekankan pada pemberian pengalaman langsung untuk mengembangkan kompetensi agar menjelajahi dan memahami alam sekitar secara ilmiah.

Wisudawati dan Sulistyowati (2015:22) berpendapat bahwa "IPA merupakan rumpunan ilmu, memiliki karakteristik khusus yaitu mempelajari fenomena alam yang faktual (factual), baik berupa kenyataan (reality) atau kejadian (events) dan hubungan sebab-akibatnya". Tujuan pembelajaran IPA agar siswa mampu menguasai konsep IPA dan berkaitannya serta mampu mengembangkan sikap ilmiah untuk memecahkan masalah-masalah yang dihadapinya. Pembelajaran IPA di sekolah pada saat ini masih belum optimal karena dalam proses pembelajarannya hanya satu arah, maka untuk mengoptimalkan pembelajaran tersebut guru harus mampu memilih/menggunakan model pembelajaran yang tepat agar poses pembelajaran lebih optimala sesuai dengan yang diinginkan dan menciptakan suasana kelas yang meriah dan menyenangkan.

Secara harfiah, Course Review Horay berasal dari bahasa inggris terdiri dari 3 kata yaitu Course yang berarti arah, tujuan mata kuliah, sajian, kuliah, rangkaian pelajaran, mata pelajaran. Review berarti tinjauan, resensi, meninjau, ulasan ulang, sedangkan Horay yaitu berarti hore, kata seru untuk menyatakan rasa gembira. Jadi Course Review Horay adalah sebuah pembelajaran dengan memberikan sajian/rangkaian pelajaran lalu memberikan ulasan dengan tinjauan kembali dan merayakannya dengan berteriak hore. Menurut Huda (2013:229) “Course Review Horay merupakan metode pembelajaran yang dapat menciptakan suasana kelas menjadi meriah dan menyenangkan karena setiap siswa yang dapat menjawab benar diwajibkan berteriak 'hore!!' atau yel-yel lainnya yang disukai". Prameswari (2017) Model pembelajaran CRH adalah salah satu pembelajaran dengan permainan yang menggunakan kotak diisi nomor soal dan siswa mengerjakan soal sesuai dengan nomor yang ada dalam kotak tersebut, siswa yang terlebih dahulu menjawab benar dengan arah horizontal, vertikal, atau diagonal lanngsung berteriang horay atau yel-yel lainnya. Jadi dapat disimpulkan Model Pembelajaran Course Review Horay digunakan untuk memberikan konsep pemahaman materi yang sulit kepada siswa serta dapat digunakan untuk mengetahui sejauh mana pengetahuan dan kemampuan siswa dalam memahami materi tersebut. 
Adapun kelebihan dari model pembelajaran course review horay antara lain: (1) strukturnya yang menarik dan dapat mendorong siswa untuk dapat terjun ke dalamnya, (2) metode yang tidak monoton karena diselingi dengan hiburan, sehingga suasana tidak menegangkan, (3) semangat belajar yang meningkat karena suasana pembelajaran berlangsung menyenangkan, dan (4) skill kerjasama antar siswa yang semakin terlatih.

Adapun kelebihan dari model pembelajaran course review horay antara lain: (1) strukturnya yang menarik dan dapat mendorong siswa untuk dapat terjun ke dalamnya, (2) metode yang tidak monoton karena diselingi dengan hiburan, sehingga suasana tidak menegangkan, (3) semangat belajar yang meningkat karena suasana pembelajaran berlangsung menyenangkan, dan (4) skill kerjasama antar siswa yang semakin terlatih.

Adapun langkah-langkah model pembelajaran Course Review Horay antara lain: Langkah 1. Menyampaikan kompetensi yang ingin dicapai, Langkah 2. Menyajikan materi sesuai dengan topikdengan Tanya jawab, Langkah 3. Membagi siswa dalam kelompok-kelompok, Langkah 4. Menguji pemahaman siswa dengan meminta siswa membuat kartu atau kotak sesuai dengan kebutuhan dan diisi dengan nomor yang ditentukan. Langkah 5. Guru membacaan soal secara acak dan siswa menuliskan jawaban di dalam kartu atau kotak yang nomornya disebutkan guru. Langkah 6. Guru dan siswa mendiskusikan soal yang telah diberikan. Langkah 7. Bagi yang benar, siswa diberi tanda check list (国) dan langsung berteriah horay atau yel-yel yang lain. Langkah 8. Nilai siswa dihitung dari jawaban yang benar dan yang banyak berteriak horay. Langkah 9. Guru meberikan reward pada yang memperoleh nilai tinggi atau yang banyak memperoleh horay. Langkah 10 (penutup)

Pembelajaran konvensional merupakan model pembelajaran yang biasa atau sering dilakukan dalam proses belajar mengajar di SD Gugus III Kuta Utara. Pembelajaran konvensional bersifat pasif karena pembelajaran hanya berpusat pada guru. Pembelajaran seperti ini masih diterapkan di sekolah dan belum mampu mengoptimalkan hasil belajar siswa khususnya pada mata pelajaran IPA. Terdapat beberapa metode pembelajaran yang sering digunakan guru dalam melakukan proses pembelajaran yakni seperti metode ceramah, metode penugasan, metode Tanya jawab. Dalam proses pembelajaran lebih sering menggunakan metode ceramah dan penugasan. Adapun kelebihan pembelajaran konvensional menurut Muslich (2009:18). adalah (1) berpusat pada potensi, perkembangan, kebutuhan, dan kepentingan peserta didik dan lingkungannya, (2) beragam dan terpadu, (3) tanggap terhadap perkembangan ilmu pengetahuan, teknologi dan seni, (4) relevan dengan kebutuhan kehidupan, (5) menyeluruh dan berkesinambungan, (6) belajar sepanjang hayat, (7) seimbang antara kepentingan nasional dan kepentingan daerah.

Dalam hal ini, pada pembelajaran konvensional peserta didik dapat dikatakan pasif karena kegiatan yang dilakukan hanyalah duduk, mendengarkan dan mencatat. Selain itu, tidak mudah bagi guru untuk mengetahui secara langsung kesulitan yang dihadapi oleh peserta didik dalam belajar karena penyampaian materi yang searah. Namun masih terdapat masalah-masalah yang terjadi dalam pembelajaran IPA, yaitu: (1) Hasil belajar IPA siswa kelas V perlu ditingkatkan, dikarenakan hasil belajar siswa masih banyak yang belum optimal, (2) Diskusi materi dengan menggunakan cara yang menarik dan bervariasi perlu dioptimalkan sehingga siswa dapat berpartisipasi dalam proses pembelajaran dan memahami materi pelajaran, (3) Model pembelajaran yang digunakan perlu divariasikan, salah satunya dalam menggunakan model pembelajaran Course Review Horay.

Hermawan Puput (2014) menyatakan dari hasil posttes dapat dilihat adanya perbedaan hasil belajar antara ke dua kelompok. Perbedaan hasil belajar IPA ini disebabkan karena pemberian perlakuan yang berbeda pada masing-masing kelompok. Kelompok eksperimen yaitu SD Negeri 1 Genengsari diberikan perlakuan dengan menggunakan dengan model kooperatif tipe Course Review Horay (CRH), sedangkan kelompok kontrol yaitu SD Negeri 3 Genengsari diberikan perlakuan dengan menggunakan model pembelajaran langsung (Direct Instruc-tion). Rukmanda Dias (2014) juga menyatakan berdasarkan hasil penelitian, dapat diambil kesimpulan bahwa penerapan Metode Pembelajaran Course Review Horay dapat meningkatkan aktivitas dan hasil belajar jurnal penyesuaian pada siswa kelas X Akuntansi SMK Muhammadiyah 2 Moyudan Tahun Ajaran 2013/2014.

Meirza Nanda (2017) juga menyimpulkan bahwa ada pengaruh yang signifikan sebesar 37,6\% model pembelajaran kooperatif tipe Course Review Horay terhadap motivasi belajar siswa pada mata pelajaran IPA di sekolah dasar. Hal senada juga diungkapkan Zainab Arrahmah (2016) yang menyatakan bahwa berdasarkan hasil penelitian dapat disimpulkan penerapan model pembelajaran Course Review Horay (CRH) dapat meningkatkan pemahaman konsep jasa dan peranan tokoh-tokoh kemerdekaan pada siswa kelas V SD Negeri 1 Mojosongo Kabupaten Boyolali tahun ajaran 2016/2017.

Mengingat masalah tersebut sangat penting diadakan penelitian dengan tujuan (1) Untuk mendeskripsikan hasil belajar IPA kelompok siswa yang dibelajarkan menggunakan model pembelajaran Course Review Horay, (2) Untuk mendeskripsikan hasil belajar IPA kelompok siswa yang dibelajarkan 
menggunakan pembelajaran konvensional, (3) Untuk mengetahui perbedaan perbedaan yang signifikan hasil belajar IPA antara kelompok siswa yang dibelajarkan menggunakan model pembelajaran Course Review Horay dan kelompok siswa yang dibelajarkan menggunakan pembelajaran konvensional siswa kelas V SD Gugus III Kuta Utara Tahun Ajaran 2017/2018.

\section{Metode}

Penelitian ini dilaksanakan pada kelas V SD Gugus III Kuta UtaraJenis penelitian yang dilakukan dalam penelitian ini adalah penelitian kuantitatif dengan desain eksprerimental yaitu quasi eksperiment (Eksperimen Semu) Desain eksperimen yang digunakan adalah Nonequevalent Control Group Design.

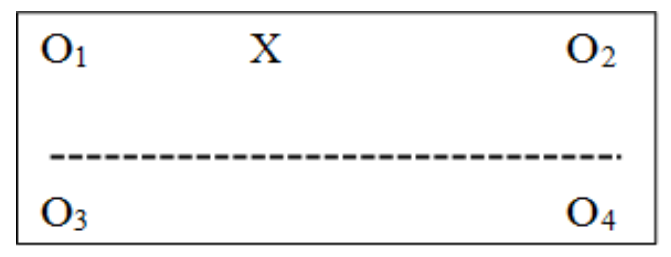

Gambar 1. Nonequivalent Control Group Design

Populasi dalam penelitian ini adalah seluruh siswa kelas V SD Gugus III Kuta Utara, yang terdiri dari 7 sekolah dengan 16 kelas dengan jumlah 527 orang siswa.

Setelah mengetahui populasi penelitian, selanjutnya adalah menentukan sampel penelitian. Sampel merupakan bagian dari populasi yang diharapkan mampu mewakili populasi dalam penelitian. Sampel adalah bagian dari jumlah dan karakteristik yang dimiliki oleh populasi tersebut (Sugiyono, 2015:118). Menurut Setyosari (2013:221) menyatakan bahwa "Sampel adalah suatu kelompok yang lebih kecil atau bagian dari populasi secara keseluruhan". Dari pengertian tersebut dapat dirangkum, sampel merupakan bagian dari populasi yang dapat mewakili populasi dalam penelitian.

Teknik pengambilan sampel pada penelitian ini adalah Random Sampling yang dirandom kelasnya, sehingga setiap kelas mendapatkan peluang yang sama untuk menjadi sampel penelitian. Pemilihan sampel penelitian ini tidak dilakukannya pengacakan individu melainkan hanya pengacakan kelas. Karena tidak bisa mengubah kelas yang telah terbentuk sebelumnya. Kelas dipilih sebagaimana telah terbentuk tanpa campur tangan peneliti dan tidak dilakukannya pengacakan individu, kemungkinana pengaruh-pengaruh dari keadaan siswa mengetahui dirinya dilibatkan dalam eksperimen dapat dikurangi sehingga penelitian ini benar-benar menggambarkan pengaruh perlakuan yang diberikan.

Untuk menentukan sampel, cara yang digunakan adalah dengan cara pengundian. Cara undian dilakukan dengan menulis semua kelas V di seluruh SD populasi pada masing-masing kertas yang jumlahnya 16 kelas, kemudian kertas digulung. Masukkan gulungan kertas ke dalam toples dan dikocok. Ambil satu gulungan kertas, lalu ambil satu gulungan kertas lain tanpa memasukkan kembali gulungan kertas pertama. Nama-nama kelas pada kedua gulungan kertas tersebut merupakan sampel penelitian. Nama kelas-kelas yang muncul pada kedua gulungan kertas yaitu kelas VA SD No.1 Kerobokan Kaja dan kelas VB SD No.2 Kerobokan Kaja.

Untuk mengetahui kesetaraan pada kelas sampel dari segi akademik maka diberikan pre-test. Nilai atai skor dari hasil pre-test yang dilakukan tersebut, digunakan untuk mengetahui kesetaraan kelas tersebut melalui uji-t. Sebelum uji kesetaraan menggunakan uji-t, maka dari hasil pre-test diuji prasyarat yaitu normalitas dan homogenitas. jika data pre-test yang diperoleh sudah memenuhi prasyarat uji normalitas dan homogenitas maka data dianalisis menggunakan uji-t dengan rumus polled varians sebagai berikut.

$$
t=\frac{\overline{X_{1}}-\overline{X_{2}}}{\sqrt{\frac{\left(n_{1}-1\right) s_{1}^{2}+\left(n_{2}-1\right) s_{2}^{2}}{n_{1}+n_{2}-2}\left(\frac{1}{n_{1}}+\frac{1}{n_{2}}\right)}}
$$

Gambar 2. rumus uji-t denganpolled varians 
Berdasarkan hasil analisi uji-t diperoleh harga $t_{\text {tabel }}$ dengan $\mathrm{dk}=35+30-2=63$ dan taraf signifikansi $5 \%$ sehingga diperoleh harga $t_{\text {tabel }}=2,000$ karena $t_{\text {hitung }}<t_{\text {tabel }}\left(t_{\text {hitung }}=0,681<t_{\text {tabel }}(\alpha=0.05,63=2,000)\right.$ maka $\mathrm{H}_{0}$ diterima dan $\mathrm{H}_{\mathrm{a}}$ ditolak sehingga kelompok setara. Setelah kedua kelompok dinyatakan setara kemudian dilakukan pengundian kembali untuk menentukan kelas eksperimen dan kelas control. Setelah dilakukan pengundian secara random, yang terpilih sebagai kelas eksperimen adalah SD No.1 Kerobokan Kaja dan kelas control adalah SD No.2 Kerobokan Kaja.

Metode pengumpulan data yang akan digunakan adalah metode tes. Menurut Arikunto (2013:67) "Tes merupakan alat atau prosedur yang digunakan untuk mengetahui atau mengukur sesuatu dalam suasana, dengan cara atau aturan-aturan yang sudah ditentukan".Tes hasil belajar IPA yang digunakan dalam penelitian ini disusun oleh peneliti sendiri. Sebelum tes tersebut diberikan kepada siswa dilakukan pengujian untuk mendapatkan gambaran secara empirik mengenai kelayakan instrumen yang akan digunakan. Untuk menguji kelayakan instrumen akan dilakukan pengujian instrumen yaitu uji validitas, uji reliabilitas, daya beda dan indeks kesukaran.

Jenis tes yang akan digunakan dalam penelitian ini untuk mengukur hasil belajar siswa adalah tes objektif dalam bentuk pilihan ganda biasa dengan 4 pilihan jawaban (A, B, C atau D) dengan jumlah pertanyaan 30 butir soal.

Teknik analisis data yang digunakan dalam penelitian ini adalah teknik analisis statistik deskriptif dan statistik inferensial. Teknik analisis dengan data kuantitatif dapat menggunakan teknik statistik deskriptif diantaranya menentukan nilai rerata (mean), simpangan baku, dan varians. Pada penelitian ini, dilakukan uji prasyarat analisis sebelum uji hipotesis dianalisis dengan uji " $\mathrm{t}$ " ( $\mathrm{t}$-test). Sebelum dilakukan uji hipotesis terlebih dahulu dilakukan uji prasyarat analisis. Ada dua uji prasyarat yang harus dipenuhi, sebelum dilakukan analisis data utama untuk menguji hipotesis penelitian yaitu uji normalitas sebaran data di tiap kelompok dan uji homogenitas varians antar kelompok.

\section{Hasil dan Pembahasan} berikut.

Berdasarkan hasil analisis yang telah dilakukan yaitu pada analisis deskriptif diperoleh data sebagai

Tabel 1. Hasil Analisis Statistik Deskriptif

\begin{tabular}{|c|c|c|}
\hline Statistik & Kelas Eksperimen & Kelas Kontrol \\
\hline Rerata & 83,54 & 75,63 \\
\hline Standar deviasi (SD) & 7,60 & 9,46 \\
\hline Varians (V) & 57,73 & 89,55 \\
\hline Jumlah data (n) & 35 & 30 \\
\hline $\mathrm{dk}$ & 34 & 29 \\
\hline
\end{tabular}

Distribusi frekuensi hasil belajar IPA kelompok eksperimen dapat disajikan dalam bentuk grafik, sebagai berikut.

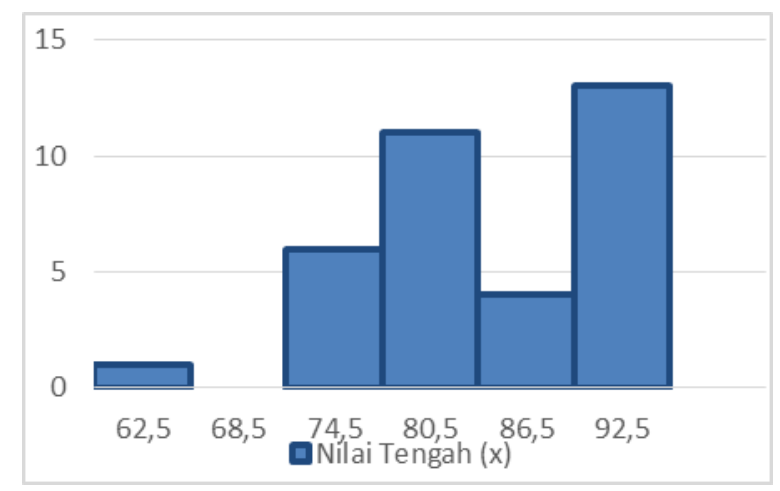

Gambar 1. Histogram Distribusi Frekuensi Hasil Belajar IPA Kelompok Eksperimen 
Berdasarkan hasil perhitungan di atas, pengelompokan distribusi frekwensi untuk hasil belajar IPA pada kelompok eksperimen diperoleh skor rata-rata $\bar{X}=83,54$ dan rerata persentase hasil belajar IPA kelompok eksperimen $\mathrm{M} \%=83,54 \%$. Rata-rata persentase hasil belajar IPA tersebut kemudian dikonversikan pada tabel PAP skala lima, sehingga dapat diketahui hasil belajar IPA siswa kelompok eksperimen berada pada kategori baik. berikut.

Distribusi frekuensi hasil belajar IPA kelompok kontrol dapat disajikan dalam bentuk grafik, sebagai

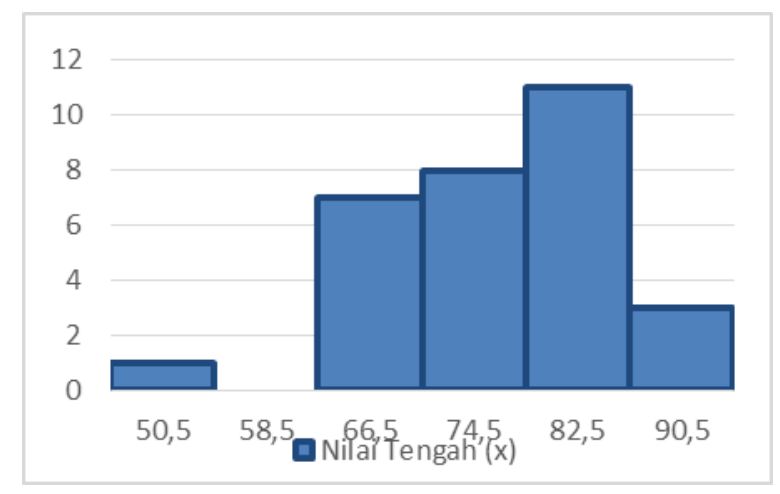

Gambar 2. Histogram Distribusi Frekuensi Hasil Belajar IPA Kelompok Kontrol

Berdasarkan hasil perhitungan di atas, pengelompokan distribusi frekwensi untuk hasil belajar IPA pada kelompok eksperimen diperoleh skor rata-rata $\bar{X}=75,63$ dan rerata persentase hasil belajar IPA kelompok kontrol M\% = 75,63 \%. Rata-rata persentase hasil belajar IPA tersebut kemudian dikonversikan pada tabel PAP skala lima, sehingga dapat diketahui hasil belajar IPA siswa kelompok kontrol berada pada kategori cukup.

Data dalam penelitian ini dapat dianalisis dengan statistik inferensial, dengan uji-t. Sebelum dilakukan uji hipotesis terlebih dahulu dilakukan uji prasyarat analisis. Ada dua uji prasyarat yang harus dipenuhi, sebelum dilakukan analisis data yaitu uji normalitas sebaran data ditiap kelompok dan uji homogenitas varians antar kelompok.

Uji normalitas dimaksudkan untuk mengetahui apakah sebaran data skor hasil belajar IPA siswa masing-masing kelompok berdistribusi normal atau tidak sehingga dapat menentukan teknik analisis datanya. Uji normalitas data dilakukan pada data hasil post-test hasil belajar IPA kelompok eksperimen dan kelompok kontrol.

Dengan ketentuan jika X2hitung < X2tabel maka data berdistribusi normal, sedangkan X2hitung > X2tabel maka data tidak berdistribusi normal. dengan derajat kebebasan $(\mathrm{db})=($ jumlah klasifikasi -1$)=(6$ 1) = 5 dan taraf signifikansi 5\%. Adapun hasil perhitungan dari uji normalitas dapat disajikan pada tabel berikut.

Tabel 2. Rekapitulasi Hasil Uji Normalitas Data

\begin{tabular}{llll}
\hline \multicolumn{1}{c}{ Sampel Penelitian } & $\mathrm{X}^{2}$ hit & $\mathrm{X}^{2}$ tabel & Keterangan \\
\hline Kelompok Eksperimen & 1,95 & 11,07 & Normal \\
\hline Kelompok Kontrol & 6,13 & 11,07 & Normal \\
\hline
\end{tabular}

Uji homogenitas varians dilakukan terhadap data hasil belajar IPA siswa kelas eksperimen dan kelas kontrol dianalisis dengan uji F. Kriteria pengujian untuk mengetahui data yang mempunyai varians yang homogen yaitu, jika $F_{\text {hit }}<F_{\text {tabel }}$ maka sampel homogen. Pengujian dilakukan pada taraf signifikan 5\% dengan derajat kebebasan untuk pembilang $\mathrm{n}_{1}-1$ dan derajat kebebasan untuk penyebut $\mathrm{n}_{2}-1$. Hasil analisi uji F untuk mengetahui homogenitas varians antara kelompok eksperimen dan kelompok kontrol dapat disajikan dlam tabel berikut. 
Tabel 3. Rekapitulasi Hasil Uji Homogenitas Varians

\begin{tabular}{|c|c|c|c|c|}
\hline Sampel & Varians & $F_{\text {hitung }}$ & $F_{\text {tabel }}$ & Kesimpulan \\
\hline Kelompok Eksperimen & 57,73 & & & \\
\hline Kelompok Kontrol & 89,55 & 1,55 & 1,85 & Homogen \\
\hline
\end{tabular}

Dari hasil uji homogenitas data hasil belajar IPA siswa kelas eksperimen dan control diperoleh $\mathrm{F}_{\text {hitung }}$ $=1,55$ sedangkan untuk taraf signifikan $5 \%$ Ftabel dengan db $(34,29)$ adalah 1,85. Ini berarti $F_{\text {hitung }}<F_{\text {tabel }}$ $(1,55<1,85)$. Hal ini menunjukkan data hasil belajar IPA antara kelompok eksperimen dan kelompok kontrol mempunyai varians yang homogen.

Berdasarkan hasil uji normalitas dan homogenitas dapat diketahui bahwa data yang diperoleh dari kelompok eksperimen dan kelompok kontrol berdistribusi normal dan memiliki varians yang homogen. Karena data yang diperoleh telah memenuhi semua prasyarat, uji hipotesis dilakukan dengan menggunakan analisis uji-t. Adapun kriteria pengujiannya adalah apabila harga $t_{\text {hitung }} \leq t_{\text {tabel, }}$, maka $H_{o}$ diterima (gagal ditolak) dan $\mathrm{H}_{\mathrm{a}}$ ditolak. Sebaliknya apabila harga $t_{\text {hitung }}>\mathrm{t}_{\text {tabel }}$ maka $\mathrm{H}_{\mathrm{o}}$ ditolak dan $\mathrm{H}_{\mathrm{a}}$ diterima. Pada taraf signifikan $5 \%(\alpha=0.05)$ dengan $\mathrm{dk}=\mathrm{n}_{1}+\mathrm{n}_{2}-2$. Adapun analisis untuk uji-t dapat disajikan pada tabel berikut.

Tabel 4. Hasil Analisis Uji-t Data Hasil Belajar IPA

\begin{tabular}{|c|c|c|c|c|c|c|c|}
\hline Sampel Kelas & $\mathrm{N}$ & $\mathrm{dk}$ & Mean & $\mathrm{S}^{2}$ & $t_{\text {hit }}$ & $t_{\text {tabel }}$ & Status \\
\hline Kelas eksperimen & 35 & & 83,54 & 57,73 & & & $\mathrm{H}_{\mathrm{O}}$ ditolak \\
\hline Kelas kontrol & 30 & 63 & 75,63 & 89,55 & 3,795 & 2,000 & \\
\hline
\end{tabular}

Dari hasil analisi uji-t diperoleh $t_{\text {hitung }}=3,795$ Harga tersebut kemudian dibandingkan dengan harga $t_{\text {tabel }}$ dengan $d \mathrm{k}=35+30-2=63$ dan taraf signifikansi $5 \%$ sehingga diperoleh harga $t_{\text {tabel }}=2,000$, karena $t_{\text {hitung }}>\mathrm{t}_{\text {tabel }}$, $\mathrm{t}_{\text {hitung }}=3,795>\mathrm{t}_{\text {tabel }}=2,000$ maka HO ditolak atau Ha diterima.

Hal ini berarti terdapat perbedaan yang signifikan hasil belajar IPA kelompok siswa yang dibelajarkan melalui model pembelajaran Course Review Horay dan kelompok siswa yang dibelajarkan melalui pembelajaran konvensional pada kelas V SD Gugus III Kuta Utara Tahun Ajaran 2017/2018. Ratarata hasil belajar IPA siswa kelompok eksperimen $\bar{X}=83,54>\bar{X}=75,63$ rata-rata hasil belajar IPA siswa kelompok kontrol. Sehingga dapat disimpulkan bahwa model pembelajaran Course Review Horay berpengaruh terhadap hasil belajar IPA siswa kelas V SD Gugus III Kuta Utara Tahun Ajaran 2017/2018.

Berdasarkan hasil penelitian, dapat dikatakan bahwa model pembelajaran Course Review Horay membuat siswa aktif, siswa dapat bekerja sama dalam kelompok, dan pembelajaran tidak membosankan karena dalam pembelajaran setiap siswa siswa yang menjawab benara akan berteriak horay atau yel-yel yang telah disepakati sebelumnya. Hal tersebut membuat pembelajaran IPA lebih dipahami oleh siswa sehingga berdampak positif terhadap hasil belajar IPA. Hal ini menyebabkan siswa dapat menerima pembelajaran IPA dengan baik.

Berbeda dengan pembelajaran konvensional yang terjadi selama pembelajaran IPA di kelompok kontrol. Kegiatan pembelajaran dilakukan dengan cara menyampaikan sejumlah materi kepada siswa yang diselingi dengan sedikit tanya jawab kemudian diikuti dengan pemberian tugas secara indvidu. Dengan pembelajaran seperti ini, siswa tidak mempunyai kesempatan untuk mengembangkan kemampuan berpikir dan kesempatan bekerjasama dengan teman sebaya, sehingga siswa akan merasa kurang tertarik saat proses pembelajaran berlangsung.

Hasil temuan ini, sejalan oleh penelitian Prameswari (2017), menyimpulkan bahwa model pembelajaran Course Review Horay dengan memanfaatkan media lingkungan sekolah sebagai sumber belajar berpengaruh terhadap kompetensi pengetahuan IPA siswa kelas V SD. Berdasarkan uraian tersebut, maka model pembelajaran Course Review Horay dapat dikatakan memberikan pengaruh yang baik terhadap hasil belajar IPA siswa. Terbukti dengan perbandingan rata-rata hasil belajar IPA siswa kelas eksperimen lebih dari rata-rata hasil belajar IPA siswa kelas kontrol.

\section{Simpulan dan Saran}

Berdasarkan hasil penelitian dan pembahasan dapat diambil beberapa simpulan sebagai berikut: (1) Berdasarkan hasil analisis data hasil belajr IPA pada kelompk eksperimen diketahui bahwa nilai rata-rata kelompok eksperimen $=83,54$ dan rerata persentase hasil belajar IPA 83,54\% dengan perolehan nilai 
minimum 60 dan nilai maksimum 93 sesuai analisis nilai hasil belajar IPA siswa kelompok eksperimen. Kemudian dibandingkan dengan nilai $\mathrm{M} \%=83,54$ yang kemudian dikonversikan pada tabel PAP skala lima. Dapat diketahui hasil belajar IPA siswa kelompk eksperimen berada pada kategori baik. (2) Berdasarkan hasil analisis data hasil belajr IPA pada kelompok kontrol diketahui bahwa nilai rata-rata kelompok kontrol $=75,63$ dan rerata persentase hasil belajar IPA 75,63\% dengan perolehan nilai minimum 47 dan nilai maksimum 90 sesuai analisis nilai hasil belajar IPA siswa kelompok kontrol. Kemudian dibandingkan dengan nilai $\mathrm{M} \%=75,63$ yang kemudian dikonversikan pada tabel PAP skala lima. Dapat diketahui hasil belajar IPA siswa kelompk kontrol berada pada kategori cukup. (3) Terdapat perbedaan yang signifikan hasil belajar IPA kelompok siswa yang dibelajarkan melalui model pembelajaran Course Review Horay dan kelompok siswa yang dibelajarkan melalui pembelajaran konvensional pada kelas V SD Gugus III Kuta Utara Tahun Ajaran 2017/2018. Itu terbukti dari hasil analisi uji-t diperoleh thitung $=3,795$ Harga tersebut kemudian dibandingkan dengan harga ttabel dengan $\mathrm{dk}=$ $34+42-2=74$ dan taraf signifikansi 5\% sehingga diperoleh harga ttabel $=2,000$, karena thitung $>$ ttabel. thitung $=3,795>$ ttabel $=2,000$ maka HO ditolak atau Ha diterima. Rata-rata hasil belajar IPA siswa kelompok eksperimen lebih dari rata-rata hasil belajar IPA siswa kelompok kontrol $(=83,54>=75,63)$. Sehingga dapat disimpulkan bahwa model pembelajaran Course Review Horay berpengaruh terhadap hasil belajar IPA siswa kelas V SD Gugus III Kuta Utara Tahun Ajaran 2017/2018.

Berdasarkan hasil penelitian, pembahasan dan simpulan, maka dapat diajukan beberapa saran kepada beberapa pihak sebagai berikut: (1) Guru hendaknya dapat menambah wawasannya mengenai inovasi pembelajaran sehingga mampu menerapkan ataupun mengembangkan pembelajaran dikelas secara lebih inovatif dan bervariasi agar dapat memberikan dampak positif dalam meningkatkan hasil belajar siswa. Salah satu model pembelajaran yang dapat direkomendasikan untuk guru dalam menciptakan pembelajarn yang bervariasi adalah model pembelajaran Course Review Horay. (2) Diharapkan sekolah memberikan sosialisasi secara berkelanjutan mengenai inovasi-inovasi pembelajaran kepada guru dalam membelajarkan siswa agar dapat mengoptimalkan hasil belajar siswa sehingga mutu sekolah menjadi semakin meningkat. (3) Peneliti lain diharapkan dapat mengembangkan berbagai model pembelajaran lain sebagai subjek penelitian yang berbeda sehingga proses pembelajaran dapat berlangsung optimal dan memberikan dampak positif bagi hasil belajar siswa.

\section{Daftar Rujukan}

Arikunto, Suharsimi. 2013. Dasar-Dasar Evaluasi Pendidikan. Jakarta: Bumi Aksara.

Dharsana, Ketut. 2017. Psikologo Pendidikan. Singaraja: UNDIKSHA.

Gagne, Robert M. 1988. Prinsip-prinsip Belajar Untuk Pengajaran. Surabaya: Usaha Nasional.

Hermawan Puput. 2014. Pengaruh Model Kooperatif Tipe Course Review Horay (CRH) terhadap Hasil Belajar IPA. Jurnal Didaktika Dwija Indria Universitas Sebelas Maret. Vol 2, No 1.

Huda, Miftahul. 2013. Model-model Pengajaran dan Pembelajaran. Yogyakarta: Pustaka Pelajar.

Kaminar. 2016. "Pendekatan Inkuiri untuk Meningkatkan Aktivitas, Partisipasi, dan Hasil belajar Siswa Pada Pembelajaran IPA". Junal Education. Volume 2, Nomor 1 (hlm. 1-10).

Kariadnyani. 2016. Pengaruh Model Course Review Horay Berbantuan Multi Media Terhadap Hasil Belajar IPA Siswa Kelas V SD. Jurnal Pendidikan Sekolah Dasar Universitas Pendidikan Ganesha Singaraja. Vol. 2, No.1.

Meirza Nanda. 2017. Pengaruh Model Pembelajaran Kooperatif Tipe Course Review Horay Terhadap Motivasi Belajar Siswa Mata Pelajaran IPA di Sekolah Dasar. ELSE (Elementary School Education Journal) : Jurnal Pendidikan dan Pembelajaran Sekolah Dasar. Vol 1, No. 2.

Pradnyani, dkk. 2013. Pengaruh Model Numbered Head Together terhadap Prestasi Belajar Matematika ditinjau dari Kebiasaan di SD". Jurnal Pendas, Vol 3, No. 1.

Prameswari, Krisna. 2017. "Pengaruh Model Pembelajaran Course Review Horay (CRH) Berbantuan Media Lingkungan Sekolah Terhadap Kompetensi Pengetahuan IPA Siswa Kelas V SD Gugus Kompyang Sujana Kecamatan Denpasar Utara". Jurnal PGSD UNDIKSHA. Volume 5, Nomor 2 (hlm. 1-11). 
Rukmanda Dias. 2014. Implementasi Metode Pembelajaran Course Review Horay untuk meningkatkan Aktivitas dan Hasil Belajar Jurnal Penyesuaian. Jurnal Pendidikan Akuntansi Indonesia, Vol. XII, No. 1

Setyosari, Punaji. 2013. Metode Penelitian Pendidikan dan Pengembangan. Jakarta: PRENADAMEDIA GROUP

Soyomukti, Nurani. 2016. Teori-teori Pendidikan. Yogyakarta: Ar-Ruzz Media.

Sugiyono. 2015. Metode Penelitian Pendidikan. Bandung: ALFABETA.

Susanto, Ahmad. 2013. Teori Belajar dan Pembelajaran di Sekolah Dasar. Jakarta: PRANADAMEDIA GROUP.

Wisudawati, Asih Widi dan Sulistyowati, Eka. 2015. Metodologi Pembelajaran IPA. Jakarta: PT Bumi Aksara.

Zainab Arrahmah. 2016. Penerapan Model Pembelajaran Course Review Horay (Crh) untuk meningkatkan Pemahaman Konsep Jasa dan Peranan Tokoh-Tokoh Kemerdekaan pada Siswa Sekolah Dasar. Jurnal Didaktika Dwija Indria UNS. Vol 2 No 1. 